\title{
Lexis
}

Journal in English Lexicology

Book reviews | 2009

\section{Elly VAN GELDEREN, A History of the English Language}

John Benjamins Publishing Company, 2006, 334 pages

\section{Jim Walker}

\section{OpenEdition}

Journals

\section{Electronic version}

URL: http://journals.openedition.org/lexis/1621

DOI: 10.4000/lexis.1621

ISSN: 1951-6215

\section{Publisher}

Université Jean Moulin - Lyon 3

\section{Electronic reference}

Jim Walker, "Elly van GeLderen, A History of the English Language », Lexis [Online], Book reviews, Online since 04 September 2009, connection on 23 September 2020. URL : http://journals.openedition.org/ lexis/1621 ; DOI : https://doi.org/10.4000/lexis.1621

This text was automatically generated on 23 September 2020 .

\section{(c) $($ ) $(9)$}

Lexis is licensed under a Creative Commons Attribution-NonCommercial-NoDerivatives 4.0 International License. 


\title{
Elly VAN GELDEREN, A History of the English Language
}

John Benjamins Publishing Company, 2006, 334 pages

\author{
Jim Walker
}

\section{REFERENCES}

Elly Van Gelderen

A History of the English Language. John Benjamins Publishing Company, 2006. ISBN :

90-272-3237-7, Prix : $33 €, 334$ pages

1 This introductory textbook into the history of the English language is divided into ten chapters. The first three are an introduction to some of the general linguistic principles that will be of importance throughout the text, such as phonetics and sound change, reconstruction methods and the place of English among the other Indo-European language families. There then follow five chapters tracing, in chronological order, the history of English from the Old English period through to Modern English, before the last two chapters look at the spread of English around the world and take a wider perspective by looking at how changes in English fit into theories about language change more generally. There are three appendices containing answers and tips to the questions posed at the end of each chapter, and an extremely interesting and useful explanation of OED research methods.

2 This review will begin with a number of negative comments, in particular about the first three chapters. The reason for this is that the author of this review feels that such comments are necessary, but that they must not detract from the laudative comments to be made further on, and with which it would be preferable to finish the review. Furthermore, it must be stressed that most of these gripes are formal in nature (with one exception to be explicated below), and can therefore be deemed to be relatively inconsequential. 
3 The text is marred in places by some rather curious formulations and strange wording. For example, on page 2 "in Britain, the Celtic languages have survived to the present in Wales, in Scotland, in Ireland, but they are not considered English." (the italics are mine). Further down the same page, we read that "English officially starts when the Germanic tribes and their languages reach the British Isles, in 449." While it is fairly clear what is meant by this notion of the "official start" of the English language, one cannot help but feel that a more rigorous wording would have been preferable here.

Similar examples are to be found on page 4: "the language currently referred to as English is the partial result of the borrowings discussed above and it can be defined as the collection of words that were selected to appear in a dictionary" which strikes me as a very unsatisfactory definition of a language, and the definition given of a standard language on page 6 also leaves a great deal to be desired: "what is often referred to as the standard language is the language of one social or regional group and is typically taught in schools, spoken (and written) by journalists. It is a formal variety or style or register." While the beginning of this definition may arguably apply to some languages, it clearly does not to English, where the standard form is precisely a non-regionalised form. Moreover, the oblique reference to journalists is somewhat strange, and the collapsing together of the terms variety, style and register is problematic, to say the very least. While it may be countered that this book is not intended as an introduction to the notion of standard English, such throwaway definitions, I feel, perhaps do more harm than good.

There may be two reasons for this unsatisfactory coverage of certain notions. The first is that the author explicitly states on page $\mathrm{x}$ of the preface that this study of the history of English will not take sociolinguistic aspects into account. This I feel is a mistake on two counts, namely that so much recent research into the history of English has amply demonstrated that the omission of social aspects is, to put it crudely, completely impossible, and secondly because the author is making a rod for her own back in the sense that when, by necessity, she does deal with basic sociolinguistic themes such as style, standard and register, it is almost inevitably wanting for detail. Another example: on page 207 we read that "some changes that first appeared in regional varieties later spread and gradually become stigmatised. These include making the interdental fricatives into stops, as in African American English, Irish English and Newfoundland English where three and tree sound the same. This use of $[t]$ and $[d]$ is a social rather than a regional variant". Leaving aside the statement that a "use" is a "variant", which is perhaps an acceptable shortcut, it is rather difficult to see how this conclusion follows, given that the author provides regional labels for what she has just discussed.

The second reason for the unsatisfactory coverage of certain notions might be more prosaic. On many occasions throughout the book, the reader gets the impression that the author has wanted to include too many details in too little space and that as a result the editing process may have been rather abrupt. The examples given above smack of rapid editing, as do a number of other passages in the text.

7 This feeling that there has been a certain degree of slapdash editing is reinforced by occasional lapses such as the fact that on page 2, there is a map refers of Viking settlements, whereas the text on page 3 claims that the map refers to Frisians, Angles and Saxons. Likewise on page 25, following a handful of old English examples given to demonstrate changes in the genitive, the author asks the question "By the way, what modern English words do you think stede and gyrnde are related to?". The second of 
these words appears in the preceding examples, but unfortunately the first one does not, something that is sure to bemuse the student keen to answer all of the exercise questions.

8 The book also contains the occasional factual error, such as the contention on page 8 that the Académie Française has established the words "chien chaud, courier [sic] électronique and ordinateur" as replacements for the English hot dog, e-mail and computer. In fact, the Académie Française has had nothing to do with any of these. The first case, the French coinage comes from Quebec and is neither used in France nor was it suggested by the Académie Française. In the second case, courrier électronique and courriel were proposed not by the Académie Française but by the Délégation Générale à la Langue Française et aux Langues de France and ordinateur was introduced into French by IBM in 1954.

9 A more general formal remark is that it is not always clear why particular words are put into bold type. This is of course often a way of indicating that a given term is to be found in a book-end glossary, but this work contains no such glossary. I did not find any indication in the preface as to how bold type was to be understood in the text. For example, on page 207 we have two words in bold type which might appear justified (variant spellings, correct pronunciation), followed, curiously, by the word 'Britain' also in bold type.

On the whole, the first chapters are disappointing. They attempt to cover far too much terrain with the inevitable result that they are somewhat sketchy. This is a genuine shame, because as the rest of this book review will seek to stress, this is an extremely interesting and useful addition to the literature on the history of English. It would be a great pity if any potential readers were put off and irritated by some of the weaknesses and lapses in the first chapters, and by the occasional strange formulations to be found elsewhere dotted in the text.

11 Let us now change the focus and move on to more positive points. The chronological chapters where we study the linguistic developments in English are genuinely excellent. The "workbook" methodology using Old English facsimiles is a great success. This is a textbook of the history of English which, while not requiring of its readers to learn the language as such, takes the interested bystander by the hand and walks him/ her through a host of relevant texts. We go beyond the textbook staple of Beowulf to take a close look at a whole variety of texts which, to me at least, were not familiar. The linguistic coverage is clear, detailed and faultless. The author is very clearly on much firmer ground when discussing the niceties of the "Exeter Book" or Caxton's "Morte d'Arthur", and these chapters are a delight to read, almost completely devoid of any of the irritations highlighted above.

12 Secondly, the reference to Web sources is extremely precious. While inherently a little unstable, they provide excellent accompaniment to the reading, and a very fruitful gateway to further study. This instability is offset by the fact that the book has a companion website (www.historyofenglish.net), which functions as a portal to all manner of resources on the history of English, and is another extremely positive aspect of the author's work.

13 Each chapter deals with a different period of English, chapter 4 on Old English, chapter 7 on Early Modern English, for example, and is divided up into sections on phonology, syntax, morphology, etc. While this may seem a fairly conventional way of introducing these aspects, the constant reference to examples from the facsimiles provided is 
always refreshing. I think it is no exaggeration to say that, despite having read quite a considerable number of textbooks on the history of English, I possibly learnt more from van Gelderen's book than from any other. One example of this is the section from page 186 to 190 , on various authorship issues, such as attempts to determine the authorship of some Shakespearean plays and other Elizabethan works. This was the first time I had seen this theme developed in a textbook of this kind and I found it fascinating. The number of original texts and facsimiles is very impressive, and they are all clearly presented and extremely useful.

14 All in all, this is a book to be recommended for those students of the history of the English looking for a practical text, covering all of the important issues, with a host of illustrative examples. The author is clearly extremely adept at explaining ancient texts, and these aspects are by far the most impressive and useful. The work as a whole is marred, as has been made clear in the foregoing, by a desire to force too much information into the book. This has led to occasional lapses in formulation and an impression that some parts of the work were done in a somewhat rushed manner. This must not, however, detract from the core of the text, which is above criticism, but it does unfortunately mean that this book cannot claim to absolute precedence among the textbooks of the history of English.

\section{AUTHORS}

\section{JIM WALKER}

Jim Walker, Centre de Recherche en Terminologie et Traduction, Université Lyon 2. Dr. Jim Walker has taught English linguistics since 1996 at the Universities of Strasbourg and Lyon 2, where he holds a Maître de Conférences position. He teaches sociolinguistics, phonology and historical linguistics to undergraduates, and sociolinguistics in MA seminars. His research revolves around the syntax and morphology of non-standard English, usually, though not exclusively, from a diachronic perspective. He holds an M.A. from the University of Cambridge in French and Linguistics, and a PhD from Paris IV (Nouvelle Sorbonne) on French sociolinguistics. He belongs to the CRTT research lab at Lyon 2 and to various linguistic societies. 